the Moghul Emperor." The above statement elearly shows that the East India Company was actually ruling the country under the shadow of the Nawab of Bengal. The Nawab was relieved of this heavy responsibility, as he got annually more than 40 lacs of rupees from the Company as lease-money. This position was cleverly stated by Clive thus, "the Nawab had only the name and shadow of authority, yet this name . . . this shadow, it is indispensably necessary that we should venerate".

This relationship should be clearly understood, as this represented the last days of the Moghul period, a dark period of the East India Company, and the formative phase of the British rule. Unless this is understood, one is liable to assume that the East India Company really represented the British Government at that time.

${ }^{1}$ Biswas, K., "150th Anniversary Volume of the Royal Botanic Garden, Calcutta", 2-12 (1942).

${ }^{2}$ Anderson, T., J. Agric. Hort. Soc. India, N.S., 1, 169 (1869).

- King, G., Ann. Roy. Bot. Gard., Calcutta, 4, Pt. 1, i-xi (1893).

'Roxburgh, W., "Hortus Bengalensis", 2 (1814).

s Roxburgh, W., "Flora Indica", 2, 629 (1832).

- This date is given as January 1, 1786, by Biswas (l.c. 2). This is probably a printer's error

'An idea of the present-day cost can be formed from the amount spent in 1944-45, which was Rs. 1,20,928.

At that time Ceylon was under the Dutch Government.

- Biswas' statement on this point is contradictory (l.c. 2). King says (l.c. 3 ) that this site was selected by Roxburgh and not by Kyd himself, as stated by Biswas.

10 Robert, P. E., "Historical Geography of the British Dependencies", 7, India, Pt. 1 (1916).

$"$ King, l.e., iii.

\section{TRACE ELEMENTS IN PLANT PHYSIOLOGY}

$U^{2}$

NDER the auspices of the International Union of Biological Sciences, a symposium on "Trace Elements in Plant Physiology" was held at Rothamsted Experimental Station, Harpenden, under the chairmanship of Prof. B. Nemec, of Prague, during November 5 and 6,1947 . Representatives from many countries attended.

The symposium was conducted in four sessions, at which fourteen short papers were read to introduce the subjects for discussion. The work in progress on trace elements under Drs. Winifred Brenchley and Katherine Warington at the Rothamsted Station was inspected at the end of the meetings.

On the evening of November 6 the members of the conference were entertained at an after-dinner function at the Rothamsted Laboratories by the Director, Dr. W. G. Ogg, and the staff of the Station, when the delegates met senior members of Rothamsted concerned with trace-element investigations.

The subjects presented in the papers for discussion covered a wide field and included items of current scientific interest and practical importance, and demonstrated the immense value of plant physiological studies in investigating problems of crop production and animal husbandry.

Prof. Nemec, in his opening address, outlined the development of methods of research on trace elements, referring in particular to the early water culture experiments of Sachs and the influence of Prof. Stoeckard, of Tharandt Forestry School, Saxony, on this pioneer work. He exhibited a sample of gold obtained from the ash of plants of Equisetum palustre grown on volcanic soils in Bohemia, and referred to the concentration of droplets of metallic mercury in the seed capsules of Holosteum umbellatum on some soils.
Prof. T. Wallace and Dr. E. J. Hewitt (Great Britain) outlined methods in use in trace-element research at Long Ashton. It was shown how visual methods can be applied to problems of deficiencies, excesses and relationships of trace elements in plant nutrition studies, and how the method can be applied to analyse the injurious effects of soil acidity. Dr. Hewitt described his technique for large-scale sand cultures by means of which he has been able to study problems relating to deficiencies of iron, manganese, boron and molybdenum. The various points of these two papers were illustrated by a comprehensive exhibit of photographs.

Prof. J. Lavollay (France) outlined his method for the determination of the coefficient of action of mineral nutrients and illustrated the application of the method to problems concerning magnesium nutrition, showing how yield is related not only to the supply of magnesium in the nutrient, but also to the total concentration of salts in the medium. $\mathrm{He}$ demonstrated the beneficial effect of phosphorus on the action of magnesium and the antagonism which exists between magnesium and potassium; also the similarity of action of potassium and rubidium.

Dr. D. I. Arnon's (U.S.A.) contribution concerned the criteria of essentiality for micro-nutrients, and he illustrated his points by reference to his investiga. tions in California on the essential role of molybdenum in plant nutrition. $\mathrm{He}$ suggested as the three criteria of essentiality of any element: (1) the life-cycle of the plant cannot be completed if the element is omitted; (2) the action of the element must be specific; (3) the effect on the plant must be direct. The paper and the discussion revealed the great practical difficulties of establishing 'essentiality' for elements required only in traces; but nevertheless it was thought that refinements of methods might disclose the essential nature of further elements.

Points of special interest in trace element nutrition were discussed in papers by Dr. E. G. Mulder (Holland), Dr. J. Erkama (Finland), and Prof. $H$. Burström (Sweden). Dr. Mulder described experiments concerning the functions of copper and molybdenum in the metabolism of higher plants and micro-organisms, and also referred to the application of his results to field crops in the Netherlands. Copper is regarded as a catalyst of oxidation processes, and molybdenum has been shown to be necessary for the reduction of nitrate nitrogen in higher plants and for the fixation of nitrogen by Azotobacter.

Dr. Erkama in his studies has regarded the three elements iron, manganese and copper as comprising one unit, and has endeavoured to determine their relationships. Manganese seems to be antagonistic to both copper and iron, and reactions with man. ganese seem to take place mainly in the vacuole sap. Copper, it is suggested, is able to remove iron from the vacuole sap and to oxidize it in protoplasm.

Prof. Burström reported results on the action of manganese in roots. Manganese appears to catalyse nitrate reduction in roots, and in this respect it may have a similar function to molybdenum in some plants. His results show that in roots, nitrogen increases the length of cells, phosphorus is concerned with cell multiplication, while manganese appears not to affect the ultimate length of the root. Manganese may shorten the meristem region, and while increasing the rate of root elongation it also shortens the 'grand period' of growth. Manganese thus seems to have effects apart from those concerned with nitrogen. Arising from this paper, the differential 
effects of $\mathrm{NH}_{4}$ and $\mathrm{NO}_{3}$ with Aspergillus, excised roots and attached roots were discussed in relation to redox systems.

The practical application of trace element investigations to crop-producing problems was discussed in the contributions of Dr. L. Gisiger (Switzerland), Prof. F. Steenbjerg (Denmark), Dr. Marie P. Löhnis (Holland), Prof. E. A. Jamalainen (Finland), and Dr. D. Mulder (Wilhelminadorp; this last being communicated by Dr. Löhnis).

Dr. Gisiger described investigations relating to crop failures in Switzerland during the War resulting from over-liming associated with deficiencies of boron and manganese. From his experiments he concludes that the damage from excess liming is due to the hydrating action of the $\mathrm{OH}^{*}$ anion. Boron tends to counteract this effect by dehydrating action, this being an alternative hypothesis to the fixation of boron by lime action. The $\mathrm{OH} \cdot$ ion is regarded as causing the unavailability of manganese over an intermediate range of $p \mathrm{H}$, availability increasing at low and high $p \mathrm{H}$ values. The range of low availability is similar to that shown by Quastel et al., at which soil organisms are active in the oxidation of soil manganese.

Prof. Steenbjerg outlined the main problems of trace elements investigated in Danish agriculture. Iron and manganese deficiencies are common in horticultural crops and copper deficiency occurs in crops on the sandy soils of Jutland. Cobalt deficiency in cattle has also been recognized. Investigations have largely concerned deficiencies of manganese and copper. With manganese the problems differ for sands and clays, and soil methods have been devised for advisory purposes. Organic matter is an important cause of copper deficiency, and the availability is greatly influenced by preceding crops. Grass is regarded as important in mobilizing soil copper. The copper content of plants has been shown not to be an infallible guide in the diagnosis of copper deficiency, since when growth is severely stunted the total copper content of the plant material (as per. centage dry matter) may not be unduly low. A characteristic S-shaped curve is obtained relating dry matter production and total copper content. Deficiency values occur up to the point of inflexion.

Discussion of this paper showed that many prob. lems concerned in availability of manganese and its relations to other elements in plants, for example, $\mathrm{Mn} / \mathrm{N}$, require further study.

Dr. Löhnis described her researches on the toxicity of manganese to crops in acid soils in the Netherlands. Phaseolus vulgaris and Vicia sativa were found to be highly susceptible, whereas oats and strawberries were resistant to damage. Resistance to excess manganese and susceptibility to manganese deficiency (as shown by oats) cannot be explained on the simple basis of 'ease of absorption of manganese' from the soil, since some crops are susceptible (for example, Phaseolus) and others resistant (for example, strawberry) to both excess and deficiency of the element.

Prof. Jamalainen gave an account of the occurrence of deficiencies of boron, copper and manganese in crops of Finland. Boron deficiency is prevalent in sugar beet, swedes and apples, and occurs even on strongly acid soils, though the deficiency is accentu. ated by liming. Other crops affected are clover, celery, turnips and white mustard.

Copper deficiency is also an important problem, particularly on peats, but also on sands. Clay soils are less affected. Cereals; hay crops, potatoes and root crops have all responded to copper dressings.

As the soils of Finland are mainly acid, manganese deficiency is rare, though marsh spot of peas has been noted in Aland. The deficiency may occur on over-limed soils.

The contribution sent by Dr. D. Mulder concerned the occurrence of zine deficiency in fruit trees in Europe and referred in particular to apples, pears and cherries in the Zeeland province of the Netherlands and to reported instances in apples in Hungary, Denmark and Switzerland. The Dutch examples occur on highly ealcareous sands, and the deficiency can be cured by winter or summer sprays of zinc sulphate.

A novel paper of the symposium was contributed by Prof. L. Seekles (Holland), in that it referred to trace-element problems in farm stock. The contribution showed clearly the similarity in plants and animals of many of the fundamental problems concerned with trace elements. Thus in both there appear to be direct and induced (or 'conditioned') deficiencies, and relationships between elements may be of great importance. Moreover, as Prof. Seekles pointed out, trace elements are concerned with many linked series of enzyme reactions in plants and animals, and the breaking of these series at different points from different deficiencies may result in varied or similar pathological conditions.

At the conclusion of the conference, Dr. D. I. Arnon proposed that an endeavour should be made to adopt a term for universal use to replace the numerous current expressions used by different workers, namely, 'trace elements', 'trace nutrients', 'minor elements', 'oligo elements', 'spuren-elements'. He was prepared to suggest the term 'micro nutrient elements' as a basis for discussion and agreed to prepare a memorandum on the subject.

\section{NEW ZEALAND DEPARTMENT OF SCIENTIFIC AND INDUSTRIAL RESEARCH}

\section{ANNUAL REPORT FOR 1946-47}

$T$ HE twenty-first annual report of the Department of Scientific and Industrial Research, New Zealand (Wellington: Gov. Printer. 1s. 9d.), includes the Minister's statement, the secretary's report for the year 1946-47, reports of the various research committees and of the Cawthron Institute, as well as reports from branches and on research work at Canterbury and Massey Agricultural Colleges. The three main new activities noted by the secretary are the establishment of a Fuel Efficiency Service in an effort to reduce the consumption of coal in industry ; the extension of the Information Bureau to deal more systematically with the exchange of information for scientific workers of the Department and the Dominion generally, and its dissemination among interested Departments and the public; and a start on the use of radioactive tracer elements in certain biological and chemical problems associated with soil processes. Building research included investigations on light. weight concrete and pumice concrete and the testing of properties of new materials, while the Plant Diseases Division examined the toxicity of wood preservatives and the treatment of infested buildings, as well as the testing of preservatives against fungi. The 